\title{
ASHA between spaces of state, empowerment and culture: A thematic review
}

\author{
Gurinder Kaur \\ Centre for Research in Rural and Industrial Development, Chandigarh, India
}

Received 31 $1^{\text {st }}$ May 2019; accepted $15^{\text {th }}$ October 2019

\section{ASHA (AKREDITOVANÝ AKTIVISTA V OBLASTI SOCIÁLNÍHO ZDRAVÍ) NA POMEZÍ STÁTU, POSÍLENÍ POSTAVENÍ ŽEN A KULTURY: TEMATICKÝ PŘEHLED}

\begin{abstract}
ABSTRAKT Cílem příspěvku je zdůraznit roli státu v posílení postavení žen ve společnosti. Zaměřuje se na komunitní zdravotnice ASHA, což jsou akreditované aktivistky v oblasti sociálního zdraví (Accredited Social Health Status Activist). Článek přináší tematický přehled založený na roli a statutu ASHA jakožto členky neo-liberálního orgánu a zároveň státního zaměstnance pod trvalým dohledem, a mimo to ženy zakotvené v pevné hierarchii byrokracie. Př́spěvek je založen na literární rešerši a přehledu zásadních výzkumů provedených v oblasti role a statutu komunitních zdravotníků v různých oblastech světa. Zabývá se představou ASHA jako spojníku a zároveň kontrastu mezi pozicemi aktivisty a zaměstnance, což přináší námět pro studium průniků mezi státem, kulturou a pohlavím.
\end{abstract}

KLÍČOVÁ SLOVA ASHA; globalizace; stát; posílení postavení žen; pohlaví

ABSTRACT Through this article the role of state in providing "empowerment" and also "controlling" those women who are a common intersecting ground for both the health care service providers and service utilisers - the community health workers like Accredited Social Health Activist (ASHA) is highlighted. The article is a thematic review based on the role and status of ASHA as a site of neoliberal agency, a state employee under constant surveillance and a woman embedded in the structure of iron cage of bureaucracy. This creates an imaginary of the ASHA as a site of confluence as well as contest between an activist and an employee, providing for a stimulating locale for intersectionality between state, culture and gender. The article is based upon readings and reviews of some significant research conducted in role and status of community health workers around the world.

KEY WORDS ASHA; globalisation; state; empowerment; gender

\section{GLOBALISATION AND MDGs}

Contextualisation of women's body politics has been understood in terms of practices of reproductive health, child birth, fertility behaviour, pregnancy, etc. cutting across the boundaries of the disciplines. These understandings have underpinnings at both local and global levels, signified by what Lock and Kaufert (1998) call, "local sites of research in order to understand better how globalisation affects body politics". The policies and frameworks designed and established at global level trickle down to national and then local levels for implementations. Formulation of Millennium Development
Goals (MDGs) in 2000 by United Nations General Assembly was one such step where global had an impact on the local. India became signatory to the MDGs as a part of 191 nations which signed and pledged to work in achieving these goals. With deadline of December 2015 past, the progress made for fulfilling these goals and sustained effort to achieve what got missed previously, Sustainable Development Goals have been formulated.

Goal 4 (reduce child mortality) and Goal 5 (improve maternal health) have direct implications for the role and status of community health workers as envisaged in the National Health Mission in context of India. National Rural Health Mission 
is a major sub-head under the ambitious Indian government programme of National Health Mission (NHM). NRHM seeks to provide quality affordable health care to the vulnerable sections in rural areas. It aims to make health care delivery accountable to the community with community involvement, decentralization, rigorous monitoring and evaluation, etc. It was envisaged in this programme to gradually shift the control of health facilities to the Panchayati Raj Institutions (considered as the third tier of Indian democracy established through $73^{\text {rd }}$ Amendment of the Indian Constitution to function at village level with the aim of decentralization of power to local governing bodies). Thus, keeping in line with global commitments India participated and pledged active involvement for fulling of all the goals. This is an apt exemplification of globalisation of the national policies. The impact and effect does not end at this alone, the effects in actuality are played at the local level influencing everyday lives of the people.

It has been acknowledged that while dealing with issues, aspects and processes that influence health of women and their agency, the structures of patriarchy cannot be ignored. However, "...this focus on patriarchy as the problem can also essentialise local spaces as static and 'traditional', and ignore broader challenges that arise during the process of translating 'universal' global policy into local context-specific practices" (Mannel 2014). It, thus, becomes an imperative exercise to understand the role of processes which go beyond the traditional and cultural factors and analyse the forces and directories of globalisation as themselves cultural tropes. In that matter, state efforts in form of policy programmes like NRHM are themselves "cultural artifacts" (Gupta and Sharma 2006). The role or rather influence of globalisation is also visible at another level - in terms of exposure of various stakeholders towards their right to health care and right to entitlements for providing health care. Lock and Kaufert (1998) to assert this note that, "globalisation has ensured that the majority of the world's people are aware...that other ways of being exist beyond the boundaries of their respective communities". The ensuing discussion elaborates on this argument where the role of ASHA workers is explored, as a case study, resultant of such global processes to serve multiple purposes envisioned with empowering section of communities as activists and yet holding in control their very move of empowerment.

\section{NRHM AND ASHA}

National Rural Health Mission (NRHM) was the initiative of the government of India, launched on 12 April 2005. The mission seeks to cater for affordable and good quality health care for the rural population of India. Large scale inequalities are observed in terms of availability and affordability of quality medical care in rural areas in India. Shortage of medical staff, especially trained doctors is a persistent problem. Thus, the programme was both welfare as well as a rights paradigm. As Roalkvam (2014) indicates, "NRHM is one important manifestation of the new techniques of governance, centred cru- cially on this notion of 'the citizen', and epitomises the broader shift in Indian development policy from a perception of development as a welfare activity of the government, to recognition of basic development as a right of citizens".

Major objectives of the mission included reduction in maternal mortality rate (MMR, the aim was to bring down MMR to 100 per 100,000 ), infant mortality rate (IMR, to bring down IMR to 30 per 100 live births) and total fertility rate (TFR, reduction to 2.1) by the end of seventh year of commencement of the programme. Significant strategies include de-centralisation, focus on reproductive maternal and child health and also specific attention on adolescents. One of the major strategies is also to empower community health workers like ASHA (Accredited Social Health Activist), who would act as facilitators, mobilisers and providers of basic health care. NRHM in this sense is not only a matter of policy but also a programme with a major focus on overcoming marginalisation of certain sections of Indian population owing to structural factors like polity, economy, geography, class, caste and gender. It is devised as a major welfare programme of the government of India with rights agenda to it.

In the entirety of this ambitious programme, participation of the community was made the basis of its structure. This programme is a veritable example of the state verticality and encompassment. According to Gupta and Ferguson (2002) "verticality refers to central and pervasive idea of the state as an institution somehow "above" civil society, community and family. Thus, state planning is inherently "top down" and state actions are efforts to manipulate and plan "from above", while "the grassroots"... is "below", closer to the ground, more authentic, and more "rooted" and "encompassment... begins with family and the local community and ends with the system of nation-states." As Gupta and Ferguson (2002) have explicated in their study, this benevolent effort of the state begins from the transnational foundations in relation to reduction of the mortality rates, enters the domain of the nation to achieve those targets through these twin processes of verticality and encompassment through the community involvement and spreads to the domain of a nation-state. Gupta (2012) observes that the Indian state rather than being "indifferent to the plight of the poor displayed great care for a segment of its population", through its welfare programmes, projects and missions like NRHM.

The ASHA workers are a very prominent link in this verticality and encompassment of the state. An ASHA under the said programme is envisaged as a young individual in the age of 25 to 45 years, with some formal educational qualification, required to attend monthly meetings at Primary Health Centers (PHCs), having local residency and selected by the Gram Panchayat. NRHM is a highly structured programme with bureaucratic hierarchies; at the lowest level are the ASHAs. The focus of this programme was community involvement, the ASHAs are selected from within the community that they reside in. Their selection involves direct participation of the village Panchayati Raj Institutions, thus the idea of including de-centralisation into the process. Work of ASHA is evalu- 
ated at multiple levels. Thus,ASHA is a "distinct site" where the state and community amalgamate. She is a site at the most basic level where the other women view and interact with the state apparatus and simultaneously she is part of state structure, under constant surveillance by hierarchical system of the programme. At the first level reporting of ASHAs is evaluated by ASHA facilitators at sub-block level, followed by block community mobiliser at block level, next level is of district coordinator at district level and lastly at state level (Guidelines for Community Processes 2013). I propose to focus on how these two distinct identities interact in the same site and how does the body politic emerge in this.

The primary focus of NRHM, and the subsequent role of ASHAs within the programme, is on provision of Primary Health Care (PHC) to the people, basically focusing upon the highly vulnerable and marginalised section of Indian population owing to factors of geography, class, caste, gender, religion and even sexual orientation. The very basic significance of the primary health care has been explicated in the Alma Ata declaration of 1978 as "Primary health care is essential health care based on practical, scientifically sound and socially acceptable methods and technology made universally accessible to individuals and families in the community through their full participation" (Maes 2015). Thus, role of social acceptability and active participation of the community has been the backbone of primary health care initiatives like NRHM.

\section{GOVERNMENTALITY AND ASHA: AN ANALYSIS}

During the 1970s the idea of community health worker (CHW) was rooted in the Alma Ata declaration of 1978 for focusing on primary health care with the aim of providing "health for all". CHW were envisaged as "agents of change" (Colvin and Swatrz 2015). The significance of their role decreased during the 1980s and 1990s but re-emerged in 2000s with increasing focus on global health and signing and adoption of MDGs. The CHWs were seen as links between culture and medicine through the state efforts. They were activists, mobilisers, rooted in the community and yet altruistic, caring and motherly. "Contemporary constructions of CHWs still imagine them to be rooted in their communities, only now the emphasis is more on their cultural competency and capacity to broker the traditional and the biomedical. They are still framed as driven by altruistic impulses, though largely moral rather than political" (Colvin and Swatrz 2015).

This aspect imbricated the idea of an activist and an agent of change with that of reproductive labour of a woman as caring and voluntary altruism. Laced with the same agenda in India, ASHA was adopted as "... a community based volunteer, receiving community based compensation...” (NRHM Mission Document 2005-12).

The very structure of NRHM and the role and status of ASHA is a paradoxical manifestation that could be aptly theorised through governmentality. Gupta and Sharma (2006) defined Foucault's concept of governmentality as a "direction toward specific ends of conduct which has its object both individual and populations which combines techniques of domination and discipline with techniques of self-government...”This is what entails the Foucauldian conception of biopower, which further entails two components of anatomo-politics and bio-politics. Where the first form enables the individual the second works at the level of the population through various institutionalised means and mechanisms. NRHM is one apt exemplification of governmentality and biopower in its two forms.

NRHM could be viewed as a welfare programme of the government of India to provide health care to the marginalised population of the country through the state apparatuses. On the other hand as a neoliberal programme it aims to create a body of independent, autonomous citizen responsible for his or her own well-being. With respect to NRHM, the duality is made visible in this context, where a section of population is dependent upon the state efforts for health requirements and other needs. The other section from the same population is utilized as an active agent of change, as a mobiliser and creating a responsible citizenry capable of looking after their own interests. The basis of idea behind the two opposing forces is to ultimately create a self-acting, responsible citizenship. Rose (2000) has identified this phenomenon as responsibilisation. Thus as Roalkvam (2014) states, "On the one hand, the NRHM seeks to guarantee governmental responsibility for an acceptable level of welfare to all citizens. On the other hand, its achievement is sought through a focus on the individual responsibility of mothers and health workers to comply and participate in the state health programme".

Apart from the beneficiary and activist dichotomy of the programme, there entails another aspect of dual contradiction in the very nature envisaged for the CHW. On the one hand there is encouragement for the bottom-up approach whereby those from the community are sought to be empowered either through participation as activists and agents of change or through processes of de-centralisation. On the other hand, the top-down vertical encompassment of the structure is to make them follow certain orders and hierarchies. Thus, "CHWs are typically portrayed as apolitical health technicians who transmit information for monitoring and evaluation, and who wield multiple technologies" (Maes 2015). This form of power is however not always accepted without resistance. There are pluralities of resistances involved, which do not necessarily aim for overthrow of the system or institutions but seek changes therein. Strikes and agitations are one form of example for this. Thus, as remarked by Lock and Kaufert (1998), subjects of governmentality or biopower are not passive in nature.

Hence, accommodating collective rights as opposed to individual choice through neoliberal practices wherein, "the political and administrative decentralisation associated with neoliberal reforms may be more empowering at a local level; if they occur at a national or aggregate level, such reforms seem disempowering or marginalising" (Ganti 2015), thus aiming to produce "highly moralised forms of citizenship" (Muehle- 
bach 2011, cf. Ganti 2015) through voluntarism and altruism. This discussion in its entirety highlights two inter-related yet paradoxical processes. First is the dialectics between the state's effort as a welfarist programme and a right based, individual responsiblised policy. The second is the two way force of globalisation where programmes and policies are created under its influence and its mechanisms, yet the same policies and programmes are also questioned by the actors who are part of the programme, even if at the lowest level.

\section{TO CONCLUDE}

ASHA and other CHWs who work at lowest rung of hierarchy of prgrammes such as NRHM, which in turn itself is a paradoxical reality, renders their role as paradoxical. Where on one hand they are projected and promoted as activists of change, yet they are also constant subjects who experience power of surveillance in various forms through various agencies. It is based upon their efforts and work where the state meets the community. They are the nodes of confluence and contestation.

In the context of governmentality and neoliberal regimes, thereof, the concepts of state, government, administration, citizen have been understood as serious efforts by the authority structures themselves to take charge of the human subjects to attain certain goals and transforming them through certain parameters. This process of transformation, especially with respect to morbidity, mortality, fertility required administration and reformation. Thus, rendering the very subjects of this control as political in nature through the movement towards the idea of government of the other to government of the self. It simultaneously creates and constraints free subjects.

This paper was an attempt, to review through prior research and concepts, to theorise the role and work of ASHA in the context of neoliberal-welfarist-globalised programme like NRHM. The idea was to problematise the role of CHWs which otherwise is taken as normalised, routinised practice of the state. The aim was what Lock and Kaufert (1998) refer "for further reflection on the way in which competing truth claims and practices are contested as a result of the ceaseless appearance of0020new knowledge which in turn provides a continual challenge to common-sense knowledge."

\section{REFERENCES}

Closser, S. (2015): Pakistan's lady health worker labour moment and the moral economy of heroism. Annals of Anthropological Practice, 39, 16-28.

Colvin, C. J. - Swartz A. (2015): Extension agents or agents of change? Community health workers and the politics of care work in post apartheid South Africa. Annals of Anthropological Practice, 39, 29-41.

Cooper, A. (2015): What does health activism mean in Venezuela's Barrio Adentro programme? Understanding the community health work in political and cultural context. Annals of Anthropological Practice, 39, 58-72.
Dean, M. (1999): Governmentality: Power and rule in modern society. London: Sage Publications.

Dreze, J. - Sen A. (2013): An uncertain glory: India and its contradictions. London: Penguin Group.

Farmer, P. - Kim, J. Y. - Kleinman, A. - Basilico, M. (2013): Reimagining global health. Berkley: University of California Press.

Ferguson, J. - Gupta, A. (2002): Spatializing state: Toward an ethnography of neoliberal governmentality. American Ethnologist, 4, 981-1002.

Foucalult, M. (1977): Discipline and punish: The birth of a prison. London: Allen Lane.

Foucault, M. (1978): History of sexuality. New York: Pantheon Books.

Ganti, T. (2015): Neoliberalism. Annual Review of Anthropology, 43, 89-104.

Gjostein, D. K. (2014): A veiled change agent: the Accredited Social Health Activist' in rural Rajasthan. In: Kenneth Bo Nielsen and Anne Waldrop (Eds.): Women, gender and everyday social transformations in India. 139156 London: Anthem Press.

Guidelines for community processes (2013): Guidelines for community processes. New Delhi: Ministry of Health and Family Welfare.

Gupta, A. (2012): Red tape: Bureaucracy, structural violence, and power in India. Hyderabad: Orient Black Swan.

Gupta, A. - Ferguson J. (2002): Spatialising states: Towards an ethnography of neoliberal governmentality. American Ethnologist, 29, 981-1002.

Gupta, A. - Sharma A. (2006): Globalisation and postcolonial states. Current Anthropology, 47, 227-307.

Hilgers, M. (2010): Three anthropological approaches to neoliberalism. International Social Science Journal, 61(202), 351-354.

Lock, M. - Kaufert, P. A. (1998): Pragmatic women and body politics. Cambridge: Cambridge University Press.

Maes, K. (2015): Community health workers and social change: An introduction. Annals of Anthropological Practice, 39: 1-15.

Mannel, J. (2014): Adopting, manipulating, transforming: tactics used by gender practitioners in South African NGOs to translate international gender policies into local practice. Health and Place, 30, 4-12.

Maupin, J. N. (2015): Shifting identities: The transformation of community health workers in highland Guatemala. Annals of Anthropological Practice, 39, 73-88.

MINISTRY OF HEALTH AND FAMILY WELFARE (n.d.) National Rural Health Mission: Framework for implementation 2005-2012. New Delhi, Government of India.

MINISTRY OF HEALTH AND FAMILY WELFARE (n.d.). National Rural Health Mission: framework for implementation 2012-2017. New Delhi, Government of India.

NATIONAL RURAL HEALTH MISSION (n.d.) National Rural Health Mission 2005-2012, Mission document. Accessed August 8, 2016, http:// nrhm.gov.in/images/pdf/guidelines/nrhm-guidelines/mission_document.pdf.

Rabinow, P. - Rose, N. (2003): Foucault today, the essential Foucault: Selection from essential works of Foucault, 1954-1984. New York: New Press.

Rainbow, P. - Rose, N. (2006): Biopower today. Biosocities, 1, 195-217.

Roalkvam, Sidsel (2014): "Health governance in India: Citizenship as situated practice", Global Public Health: An International Journal for Research, Policy and Practice, 9, 910-926.

Rose, N. (2000): Government and control. British Journal of Criminology, 40, 321-339.

\section{AUTHOR}

Kaur, Gurinder - Assistant Professor, Centre for Research in Rural and Industrial Developmnet, Sector $19 \mathrm{~A}$, Chandigarh, India.

Contact: gurinderkaur1725@gmail.com 